\title{
Pengaruh Motivasi Kerja terhadap Kinerja Karyawan Wilayah Telkom Jabar Barat Utara (Witel Bekasi)
}

\author{
Sindi Larasati \\ Ilmu Administrasi Bisnis, Fakultas Komunikasi dan Bisnis \\ Universitas Telkom Bandung \\ e-mail: sindi.larasati@gmail.com \\ Alini Gilang \\ Ilmu Administrasi Bisnis, Fakultas Komunikasi dan Bisnis \\ Universitas Telkom Bandung
}

\begin{abstract}
Human resources are incredibly crucial for companies, playing a role as a driven tigger of all company activities. By having qualified human resources, the company can easily integrate both its vision ang goals to the employees so that the company's goals can be achieved. This research was conducted in Telkom Jabar Barat Utara (Witel Bekasi) by using work motivation as the independent variable and performance as the dependent variable. The purpose of this study is to determine the influence of work motivation, consisting of need for achievement, need for affiliation and need for power on the performance of the employees of Witel Bekasi. This research is descriptive and causal. Data were analyzed by using descriptive analysis, multiple linear regression analysis, simultaneous hypothesis test (F test), the partial hypothesis testing (t-test), and the coefficient of determination. Sampling technique used is Proportionate Stratified Random Sampling. Based on the results of the questionnaire with 180 respondents, the assessment of employees' work motivation and performance are in the category of very high. In the hypothesis testing results, it can be concluded that the work motivation variable $(X)$ consisting of Need for Achievement $\left(X_{1}\right)$, Need for Affiliation $\left(X_{2}\right)$ and Need for Power $\left(X_{3}\right)$ simultaneously and partially had significant effect on employee performance $(Y)$. In the test results the coefficient of determination $\left(R^{2}\right)$ obtained a value of 0.551 , this means that the influence of work motivation on employee performance was $55.1 \%$, while the remaining $44.9 \%$ influenced by other factors was not examined in this study.
\end{abstract}

Keywords: work motivation, employee performance, human resource, human capital, witel bekasi.

\begin{abstract}
ABSTRAK
Sumber daya manusia (SDM) penting bagi perusahaan karena memiliki peran sebagai potensi penggerak seluruh aktivitas perusahaan. Perusahaan yang memiliki SDM yang berkualitas dapat dengan mudah mengintegrasikan visi perusahaan dengan tujuan perusahaan kepada karyawannya sehingga pencapaian tujuan perusahaan bisa tercapai. Penelitian ini dilakukan di Wilayah Telkom Jabar Barat Utara (Witel Bekasi) dengan menggunakan motivasi kerja sebagai variabel independen dan kinerja sebagai variabel dependen. Tujuan penelitian ini untuk mengetahui bagaimana pengaruh motivasi kerja yang terdiri dari kebutuhan prestasi, kebutuhan afiliasi dan kebutuhan kekuasaan terhadap kinerja karyawan Witel Bekasi. Penelitian ini merupakan penelitian deskriptif dan kausal. Analisis data yang digunakan adalah analisis deskriptif, analisis regresi linier berganda, uji hipotesis secara simultan (uji F), uji hipotesis secara parsial (uji t), dan koefisien determinasi. Teknik sampel yang digunakan adalah Proportionate Stratified Random Sampling. Berdasarkan hasil kuesioner dengan 180 orang responden, penilaian karyawan terhadap motivasi kerja dan kinerja termasuk dalam kategori sangat tinggi. Pada
\end{abstract}


hasil pengujian hipotesis dapat disimpulkan bahwa variabel Motivasi Kerja $(X)$ yang terdiri dari Kebutuhan Prestasi $\left(X_{1}\right)$, Kebutuhan Afiliasi $\left(X_{2}\right)$ dan Kebutuhan Kekuasaan $\left(X_{3}\right)$ secara simultan dan parsial berpengaruh signifikan terhadap Kinerja Karyawan $(Y)$. Pada hasil uji koefisien determinasi $\left(R^{2}\right)$ diperoleh nilai sebesar 0.551 . Hal ini berarti bahwa besarnya pengaruh motivasi kerja terhadap kinerja karyawan adalah sebesar $55.1 \%$, sedangkan sisanya $44.9 \%$ dipengaruhi faktor-faktor lain yang tidak diteliti dalam penelitian ini.

Kata kunci: motivasi kerja, kinerja karyawan, sumber daya manusia, human capital, witel bekasi.

\section{Pendahuluan}

Sumber daya manusia (SDM) memiliki peran penting sebagai potensi penggerak seluruh aktivitas perusahaan. Setiap perusahaan harus bisa menjaga, memelihara dan meningkatkan kualitas kinerja SDM yang dimiliki. Salah satu cara yang dapat dilakukan oleh perusahaan dalam meningkatkan kualitas kinerja adalah dengan memberikan perhatian berupa motivasi kerja kepada karyawannya. Selain itu, hal terpenting yang harus dilakukan oleh perusahaan, adalah bagaimana karyawan dapat menikmati pekerjaannya sehingga karyawan dapat mengerjakan perkerjaannya tanpa ada tekanan. Berdasarkan hasil penelitian Suwardi dan Utomo (2011), Hamid (2012), Murti dan Veronika (2013), serta Permansari (2013) ditemukan bahwa motivasi kerja secara signifikan memiliki pengaruh positif terhadap kinerja karyawan. Penelitian lain yang dilakukan oleh Salleh et al. (2011) serta penelitian dari Susan et al. (2012) juga menyatakan bahwa motivasi kerja memiliki pengaruh positif dan signifikan pada kinerja karyawan.

Dengan memiliki sumber daya manusia yang unggul, perusahaan akan lebih mudah bersaing dalam dunia bisnis saat ini yang sudah mulai memasuki era globalisasi. Pada era globalisasi ini persaingan bisnis akan semakin ketat, karena tidak hanya bersaing dengan produk lokal saja tetapi juga dengan produk mancanegara yang diimpor ke dalam negeri. Persaingan bisnis ini juga berpengaruh pada industri telekomunikasi. Perusahaan telekomunikasi di Indonesia saat ini sudah semakin banyak, seperti PT. Telkom Indonesia, Tbk, PT. Indosat, Tbk, PT. XL Axiata, Tbk dan sebagainya. PT. Telkom Indonesia, Tbk sebagai perusahaan penyelenggara layanan telekomunikasi dan jaringan terbesar di Indonesia memiliki produk dan layanan yang beragam dan berhasil menguasai pangsa pasar sebesar $42 \%$.

PT. Telkom Indonesia, Tbk dibagi menjadi dua, yaitu Divisi Telkom Barat dan Divisi Telkom Timur. Wilayah Telkom Jabar Barat Utara atau Witel Bekasi merupakan salah satu wilayah di Divisi Telkom Barat yang berlokasi di Jalan Rawa Tembaga No. 4 Bekasi. Witel Bekasi bergerak di bidang operasional Telkom seperti pemasaran produk atau layanan, penanganan keluhan, perbaikan produk atau layanan dan sebagainya. Pemasaran produk atau layanan di Witel Bekasi, fokus pada penjualan Speedy, Wireline dan UseeTV. Untuk mencapai target perusahaan maka perusahaan harus meningkatkan kualitas kinerja karyawannya sehingga dapat memberikan kepuasan kepada pelanggan. Tabel 1 berikut adalah pencapaian target penjualan Speedy, Wireline dan UseeTV tahun 2012-2013. 
Tabel 1. Data pencapaian target penjualan Speedy, Wireline dan UseeTV di Wilayah Telkom Jabar Barat Utara (Witel Bekasi) Tahun 2012-2013

\begin{tabular}{lcccccc}
\hline \multirow{2}{*}{ Produk/Layanan } & \multicolumn{3}{c}{2012} & & 2103 \\
\cline { 2 - 7 } & $\begin{array}{c}\text { Total Target } \\
\text { (Unit) }\end{array}$ & $\begin{array}{c}\text { Total Realisasi } \\
\text { (Unit) }\end{array}$ & $\%$ & $\begin{array}{c}\text { Total Target } \\
\text { (Unit) }\end{array}$ & $\begin{array}{c}\text { Total Realisasi } \\
\text { (Unit) }\end{array}$ & $\%$ \\
\hline Speedy & 9928 & 22263 & 224.24 & 38346 & 20036 & 52.25 \\
Wireline & 14135 & 16881 & 119.42 & 12491 & 18875 & 145.50 \\
UseeTV & - & - & - & 5918 & 2110 & 35.66 \\
\hline
\end{tabular}

Sumber : Unit Bisnis War-Room (2012-2013)

Berdasarkan Tabel 1, jumlah target penjualan yang ingin dicapai pada tahun 2012 sebesar 9928 unit, sedangkan realisasi penjualan sebesar 22263 unit dengan persentase keberhasilan 224.24\%. Keberhasilan penjualan ini memicu semangat karyawan Witel Bekasi untuk melakukan penjualan yang lebih baik di tahun 2013 dengan menaikkan jumlah target penjualan sebesar $286.24 \%$ menjadi 38346 unit. Akan tetapi realisasi penjualan yang terjadi di tahun 2013 tidak sebaik di tahun 2012. Total penjualan yang berhasil dicapai hanya sebesar 20036 unit dengan persentase keberhasilan 52.85\%. Apabila dibandingkan dengan penjualan di tahun 2012, penjualan di tahun 2013 mengalami penurunan penjualan sebesar 2227 unit.

Penjualan Wireline di tahun 2012 dan 2013 dapat mencapai target penjualan, bahkan melebihi dari jumlah target yang seharusnya dicapai. Berdasarkan data Tabel 1 , pada tahun 2012 total target penjualan yang ingin dicapai sebesar 14135 unit, sedangkan realisasi penjualan yang terjadi mencapai 16.881 unit dengan persentase keberhasilan sebesar $119.42 \%$. Begitu pula di tahun 2013, pencapaian target penjualan di tahun 2013 dapat diraih pada penjualan Wireline di Witel Bekasi. Penjualan Wireline di tahun 2013 mengalami peningkatan penjualan sebesar 1294 unit menjadi 18175 unit dari total target yang ingin dicapai sebesar 12491 unit. Persentase keberhasilan penjualan Wireline di tahun 2013 adalah sebesar 145.50\%. Tetapi jika dilihat dari jumlah target penjualan yang ingin dicapai di tahun 2013 (sebesar 12491 unit) mengalami penurunan sebesar 1644 unit dibanding jumlah target penjualan yang ingin dicapai di tahun 2012 (sebesar 14135 unit).

Penjualan UseeTV di Witel Bekasi tidak dapat mencapai target penjualan yang sudah ditetapkan. UseeTV merupakan layanan terbaru dari Telkom yang diluncurkan pada bulan Agustus 2012. Namun penjualan UseeTv di Witel Bekasi baru dimulai pada tahun 2013. Pada bulan Januari hingga Maret 2013 Witel Bekasi belum menetapkan target penjualan untuk UseeTV dan mulai bulan April 2013 Witel Bekasi baru menetapkan target penjualan. Dari Tabel 1 dapat dilihat bahwa total target penjualan UseeTV di tahun 2013 yang ingin dicapai adalah sebesar 5918 unit, sedangkan realisasi penjualan yang terjadi hanya mencapai 2110 unit dengan persentase keberhasilan sebesar $35.66 \%$. Salah satu penyebab dari hasil penjualan yang kurang baik tersebut adalah karena ketidaksiapan infrastruktur yang kurang memadai sehingga sistem yang digunakan pada UseeTV tidak dapat berfungsi. Selain itu, banyaknya pelanggan yang 
belum mengenal produk atau layanan UseeTV yang mengakibatkan kurangnya minat beli terhadap produk atau layanan ini.

Tujuan dari penelitian ini adalah 1) Mengkaji dan menganalisis motivasi kerja (kebutuhan prestasi, kebutuhan afiliasi dan kebutuhan kekuasaan) karyawan Witel Bekasi; 2) Mengkaji dan menganalisis kinerja karyawan Witel Bekasi; 3) Mengkaji dan menganalisis pengaruh motivasi kerja (kebutuhan prestasi, kebutuhan afiliasi dan kebutuhan kekuasaan) terhadap kinerja karyawan Witel Bekasi secara simultan dan parsial dan 4) Mengkaji dan menganalisis seberapa besar pengaruh motivasi kerja (kebutuhan prestasi, kebutuhan afiliasi dan kebutuhan kekuasaan) terhadap kinerja karyawan Witel Bekasi secara simultan dan parsial.

\section{Metode Penelitian}

Jenis penelitian ini adalah deskriptif dan kausal. Pada penelitian deskriptif akan dideskripsikan bagaimana motivasi kerja dan kinerja karyawan di Witel Bekasi. Penelitian ini juga menggunakan metode kausal karena satu dari empat rumusan masalah pada penelitian ini menanyakan hubungan sebab akibat antar dua variabel. Pada penelitian kausal akan menguji bagaimana pengaruh motivasi kerja terhadap kinerja karyawan di Witel Bekasi. Penelitian ini dilakukan di Witel Bekasi yang berlokasi di Jalan Rawa Tembaga No 4 Bekasi dengan periode penelitian dari bulan Februari 2014-Juli 2014.

Variabel Operasional yang digunakan pada penelitian ini adalah:

1. Variabel Independen

Variabel independen atau variabel bebas yang digunakan pada penelitian ini adalah variabel Motivasi Kerja (X) berdasarkan Teori Motivasi McClelland sebagaimana dikutip oleh Mangkunegara (2007).

a. Kebutuhan Prestasi $\left(\mathrm{X}_{1}\right)$ :
1) Inovasi
2) Kreativitas
3) Umpan Balik
4) Tantangan
5) Semangat Kerja

b. Kebutuhan Afiliasi $\left(X_{2}\right)$ :

1) Sosialisasi

2) Hubungan Antar Pribadi

3) Persahabatan

c. Kebutuhan Kekuasaan $\left(\mathrm{X}_{3}\right)$ :

1) Kompetisi

2) Wewenang

3) Kedudukan

2. Variabel Dependen

Variabel dependen atau variabel terikat yang digunakan pada penelitian ini adalah variabel Kinerja Karyawan (Y) berdasarkan konsep Wirawan (2009).

a. Hasil Kerja

b. Perilaku Kerja 
c. Sifat Pribadi yang ada hubungannya dengan pekerjaan

Populasi pada penelitian ini adalah seluruh karyawan di Witel Bekasi sebanyak 284 orang, yang dikategorikan berdasarkan posisi atau jabatan yaitu posisi atau jabatan General Manager, Manager, Assistant Manager, Senior Supervisor, Supervisor, dan Staff. Berikut adalah jumlah karyawan di Witel Bekasi berdasarkan posisi atau jabatan.

Tabel 2. Jumlah karyawan Witel Bekasi

\begin{tabular}{lc}
\hline \multicolumn{1}{c}{ Posisi/Jabatan } & $\begin{array}{c}\text { Jumlah Karyawan } \\
\text { (orang) }\end{array}$ \\
\hline General Manager & 1 \\
Manager & 10 \\
Assistant Manager & 27 \\
Senior Supervisor & 62 \\
Supervisor & 175 \\
Staff & 9 \\
\hline \multicolumn{1}{c}{ Total } & 284 \\
\hline
\end{tabular}

Sumber : Unit Bisnis Human Resource Witel Bekasi (2013)

Pada penelitian ini pengambilan sampel dari populasi menggunakan rumus Slovin (Umar 2008).

$$
n=\frac{N}{1+N e^{2}}=\frac{284}{1+\left(284 \times(0,05)^{2}\right)}=166
$$

di mana :

$n=$ Ukuran sampel

$N=$ Ukuran populasi

$e=$ Batas toleransi kesalahan (menggunakan 5\%)

Berdasarkan penghitungan sampel di atas, jumlah sampel yang akan digunakan dalam penelitian ini adalah 166 responden dari total populasi sebanyak 284 karyawan. Sebagai tindak antisipasi, apabila terdapat responden yang tidak dapat ditemui atau kejadian tak terduga lainnya, maka untuk proses pengumpulan data, jumlah responden dibulatkan menjadi 180 orang.

Sedangkan untuk proporsi pengambilan sampel, karena populasi mempunyai persebaran yang berbeda di setiap unit bisnis, maka teknik pengambilan sampel yang digunakan adalah teknik Proportionate Stratified Random Sampling yang merupakan salah satu teknik Propabilitiy Sampling, yaitu teknik yang digunakan apabila populasi mempunyai anggota/unsur yang tidak homogen dan berstrata secara proporsional (Sugiyono 2011). Proporsi pengambilan sampel dari setiap karyawan unit bisnis rumus (Sedarmayanti dan Hidayat 2011) :

$$
n_{i}=\frac{N_{i}}{N} \times n
$$

di mana :

$n_{i}=$ Jumlah sampel menurut strata

$n=$ Jumlah sampel seluruhnya

$N_{i}=$ Jumlah populasi menurut strata 
$N=$ Jumlah populasi seluruhnya

Tabel 3. Proporsi jumlah sampel di setiap posisi/jabatan

\begin{tabular}{lccc}
\hline \multicolumn{1}{c}{ Posisi } & $\begin{array}{c}\text { Jumlah } \\
\text { (orang) }\end{array}$ & Sampel & $\begin{array}{c}\text { Jumlah } \\
\text { (orang) }\end{array}$ \\
\hline General Manager & 1 & $1 / 284 \times 180$ & 1 \\
Manager & 10 & $10 / 284 \times 180$ & 6 \\
Assistant Manager & 27 & $27 / 284 \times 180$ & 17 \\
Senior Supervisor & 62 & $62 / 284 \times 180$ & 39 \\
Supervisor & 175 & $175 / 284 \times 180$ & 111 \\
Staff & 9 & $9 / 284 \times 180$ & 6 \\
\hline \multicolumn{1}{c}{ Total } & $\mathbf{2 8 4}$ & & $\mathbf{1 8 0}$ \\
\hline
\end{tabular}

Sumber : Data diolah (2014)

Sugiyono (2011) menyatakan bahwa statistik deskriptif adalah statistik yang digunakan untuk menganalisis data dengan cara mendeskripsikan atau menggambarkan data yang telah terkumpul sebagaimana adanya tanpa bermaksud membuat kesimpulan yang berlaku untuk umum atau generalisasi. Analisis deskriptif digunakan untuk menganalisis atau menggambarkan motivasi kerja dan kinerja karyawan di Witel Bekasi.

Analisis regresi linier berganda digunakan untuk mengetahui besarnya pengaruh variabel bebas, yaitu Kebutuhan Prestasi $\left(X_{1}\right)$, Kebutuhan Afiliasi $\left(X_{2}\right)$, Kebutuhan Kekuasaan $\left(\mathrm{X}_{3}\right)$ terhadap variabel terikat yaitu Kinerja $(\mathrm{Y})$. Bentuk persamaan regresi linier berganda yang digunakan dalam penelitian ini adalah sebagai berikut (Riduwan 2009):

$$
Y=a+b_{1} X_{1}+b_{2} X_{2}+b_{3} X_{3}+e \ldots \ldots(2)
$$

Keterangan:

$\mathrm{Y} \quad=$ Kinerja (variabel dependen)

a $\quad=$ Konstanta dari keputusan regresi

$b_{1} \quad=$ Koefisien regresi dari variabel $X_{1}$ (Kebutuhan Prestasi)

$b_{2} \quad=$ Koefisien regresi dari variabel $X_{2}$ (Kebutuhan Afiliasi)

$b_{3} \quad=$ Koefisien regresi dari variabel $X_{3}$ (Kebutuhan Kekuasaan)

$X_{1}=$ Kebutuhan Prestasi (variabel independen)

$X_{2}=$ Kebutuhan Afiliasi (variabel independen)

$X_{3}=$ Kebutuhan Kekuasaan (variabel independen)

e $=$ Error

Pengujian hipotesis secara simultan (Uji F) digunakan untuk menguji besarnya pengaruh variabel bebas terdiri dari Kebutuhan Prestasi $\left(X_{1}\right)$, Kebutuhan Afiliasi $\left(X_{2}\right)$ dan Kebutuhan Kekuasaan $\left(X_{3}\right)$ secara simultan atau bersama-sama berpengaruh terhadap Kinerja Karyawan (Y) di Witel Bekasi. Pengujian dilakukan menggunakan tabel distribusi $\mathrm{F}$ dengan taraf signifikansi 5\%. Kriteria pengambilan keputusan pada pengujian ini adalah sebagai berikut:

1. $F_{\text {hitung }} \leq F_{\text {tabel }}$ maka $\mathrm{H}_{0}$ diterima dan $\mathrm{H}_{\mathrm{a}}$ ditolak, artinya variabel bebas (Kebutuhan Prestasi, Kebutuhan Afiliasi dan Kebutuhan Kekuasaan) tidak berpengaruh secara simultan terhadap variabel terikat (Kinerja Karyawan). 
2. $F_{\text {hitung }}>F_{\text {tabel }}$ maka $\mathrm{H}_{0}$ ditolak dan $\mathrm{H}_{\mathrm{a}}$ diterima, artinya variabel bebas (Kebutuhan Prestasi, Kebutuhan Afiliasi dan Kebutuhan Kekuasaan) berpengaruh secara simultan terhadap variabel terikat (Kinerja Karyawan).

Untuk mencari pembuktian hipotesis, peneliti menggunakan uji signifikansi koefisien regresi secara parsial (Uji t). Uji signifikansi terhadap masing-masing koefisien regresi diperlukan untuk mengetahui signifikan tidaknya pengaruh dari masing-masing variabel bebas $(\mathrm{X})$ terhadap variabel terikat $(\mathrm{Y})$. Berkaitan dengan hal ini, uji signifikansi secara parsial digunakan untuk menguji hipotesis penelitian (Sanusi 2011). Pada penelitian ini, kegunaan Uji $t$ ini adalah untuk menguji apakah variabel Motivasi Kerja $(\mathrm{X})$ secara parsial berpengaruh terhadap variabel Kinerja Karyawan (Y).

Adapun langkah-langkah untuk uji t adalah:

1. Hipotesis yang digunakan pada penelitian ini adalah:

$H_{0}: b_{i}=0$, Variabel bebas (Kebutuhan Prestasi, Kebutuhan Afiliasi dan Kebutuhan Kekuasaan) tidak berpengaruh signifikan secara parsial terhadap variabel terikat (Kinerja Karyawan).

$\mathrm{H}_{1}: \mathrm{b}_{\mathrm{i}} \neq 0$, Variabel bebas (Kebutuhan Prestasi, Kebutuhan Afiliasi dan Kebutuhan Kekuasaan) berpengaruh signifikan secara parsial terhadap variabel terikat (Kinerja Karyawan).

2. Menentukan nilai kritis dengan level of significant $=5 \%(0.05)$

3. Penentuan kriteria penerimaan dan penolakan

a. $-t_{\text {tabel }} \leq t_{\text {hitung }} \leq t_{\text {tabel }}$ maka $\mathrm{H}_{0}$ diterima dan $\mathrm{H}_{1}$ ditolak

b. $t_{\text {hitung }}<-t_{\text {tabel }}$ atau $t_{\text {hitung }}>t_{\text {tabel }}$ maka $\mathrm{H}_{0}$ ditolak dan $\mathrm{H}_{1}$ diterima

Penelitian ini menggunakan program SPSS. Penafsiran pengujian hipotesis adalah sebagai berikut:

1. Jika nilai probabilitas $<\alpha(5 \%)$ maka $H_{0}$ ditolak sehingga ada hubungan signifikan secara parsial antara variabel dependen dengan variabel independen

2. Jika tingkat probabilitas signifikannya $\geq \alpha(5 \%)$ maka $\mathrm{H}_{0}$ diterima sehingga tidak ada hubungan signifikan secara parsial antara variabel dependen dengan variabel independen.

Koefisien determinasi merupakan kuadrat dari koefisien korelasi $\left(r^{2}\right)$ yang berkaitan dengan variabel bebas dan variabel terikat. Secara umum dikatakan bahwa $r^{2}$ merupakan kuadrat korelasi antara yang digunakan sebagai predictor dan variabel yang memberikan response. Koefisien determinasi digunakan sebagai upaya melihat besarnya pengaruh variabel bebas terhadap variabel terikat (Abdurrahman et al. 2011).

Rentang nilai koefisien determinasi adalah 0 - 1 dengan asumsi $\left(0 \leq r^{2} \geq 1\right)$. Apabila koefisien determinasi memiliki nilai yang kecil dapat dikatakan kemampuan variabel independen dalam menjelaskan variasi variabel dependen terbatas. Begitu pula sebaliknya, apabila koefisien determinasi memiliki hasil mendekati 1 dapat dikatakan variasi variabel independen hampir dapat memberikan informasi maupun instruksi yang dibutuhkan untuk memprediksi variasi variabel dependen. Semakin tinggi $r^{2}$ atau mendekati satu maka model yang digunakan semakin baik. Adapun rumus koefisien determinasi adalah sebagai berikut (Abdurrahman et al. 2011)

$$
K P=r^{2} \times 100 \% \ldots \ldots \ldots \ldots(3)
$$


Di mana :

$\mathrm{KP} \quad=$ Nilai Koefisien Determinasi

$r^{2} \quad=$ Nilai Koefisien Korelasi

\section{Hasil dan Pembahasan}

III.1. Analisis Deskripsif Tanggapan Responden Mengenai Motivasi Kerja (X)

Motivasi kerja merupakan suatu dorongan yang diberikan kepada karyawan agar mereka mau bekerja keras dan berusaha memberikan yang terbaik bagi perusahaan. Motivasi kerja pada penelitian ini dijadikan sebagai variabel bebas yang terdiri dari tiga sub variabel dengan total indikator sebanyak sebelas indikator. Sub variabel yang pertama adalah kebutuhan prestasi dengan indikator yang digunakan adalah inovasi, kreativitas, umpan balik, tantangan, dan semangat kerja.

Sub variabel yang kedua adalah kebutuhan afiliasi dengan indikatornya adalah sosialisasi, hubungan antar pribadi dan persahabatan. Sub variabel yang ketiga adalah kebutuhan kekuasaan dan indikator yang digunakan adalah kompetisi, wewenang dan kedudukan. Berikut ini adalah hasil analisis tanggapan responden menegenai kebutuhan prestasi, kebutuhan afiliasi dan kebutuhan kekuasaan.

\section{Analisis Deskriptif Tanggapan Responden Mengenai Kebutuhan Prestasi $\left(\mathrm{X}_{1}\right)$}

Tabel 4. Tanggapan responden mengenai kebutuhan prestasi $\left(X_{1}\right)$

\begin{tabular}{|c|c|c|c|c|c|c|c|c|c|}
\hline Item & Pertanyaan & 5 & 4 & 3 & 2 & 1 & Jumlah & $\begin{array}{l}\text { Skor } \\
\text { Total }\end{array}$ & $\begin{array}{l}\text { Skor } \\
\text { Ideal }\end{array}$ \\
\hline 1 & Selalu melakukan inovasi & 63 & 112 & 5 & 0 & 0 & 180 & 778 & 900 \\
\hline 2 & Memiliki kreativitas yang tinggi & 54 & 117 & 5 & 1 & 3 & 180 & 758 & 900 \\
\hline 3 & $\begin{array}{l}\text { Selalu mengharapkan umpan } \\
\text { balik }\end{array}$ & 54 & 117 & 5 & 1 & 3 & 180 & 758 & 900 \\
\hline 4 & $\begin{array}{l}\text { Siap dalam menghadapi } \\
\text { tantangan }\end{array}$ & 61 & 115 & 4 & 0 & 0 & 180 & 777 & 900 \\
\hline 5 & $\begin{array}{l}\text { Memiliki semangat kerja yang } \\
\text { tinggi }\end{array}$ & 78 & 100 & 2 & 0 & 0 & 180 & 796 & 900 \\
\hline \multicolumn{8}{|c|}{ Jumlah Skor Total } & \multicolumn{2}{|c|}{3872} \\
\hline \multicolumn{8}{|c|}{ Persentase Skor } & \multicolumn{2}{|c|}{$86.11 \%$} \\
\hline
\end{tabular}

Sumber : Data diolah (2014)

Dari perhitungan dalam tabel menunjukkan nilai yang diperoleh sebesar 3872 atau $86.11 \%$. Dengan demikian Kebutuhan Prestasi berada pada kategori sangat tinggi yang menunjukkan bahwa karyawan di Witel Bekasi memiliki motivasi yang tinggi dalam mencapai prestasi yang sangat tinggi pula.

2. Analisis Deskriptif Tanggapan Responden Mengenai Kebutuhan Afiliasi $\left(\mathrm{X}_{2}\right)$

\begin{tabular}{|c|c|c|c|c|c|c|c|c|c|}
\hline Item & Pertanyaan & 5 & 4 & 3 & 2 & 1 & Jumlah & $\begin{array}{l}\text { Skor } \\
\text { Total }\end{array}$ & $\begin{array}{l}\text { Skor } \\
\text { Ideal }\end{array}$ \\
\hline 1 & Kekerabatan terjalin dengan baik & 87 & 90 & 3 & 0 & 0 & 180 & 804 & 900 \\
\hline 2 & $\begin{array}{l}\text { Memiliki hubungan yang baik } \\
\text { dengan rekan kerja }\end{array}$ & 95 & 83 & 2 & 0 & 0 & 180 & 813 & 900 \\
\hline
\end{tabular}


Lanjutan Tabel 5

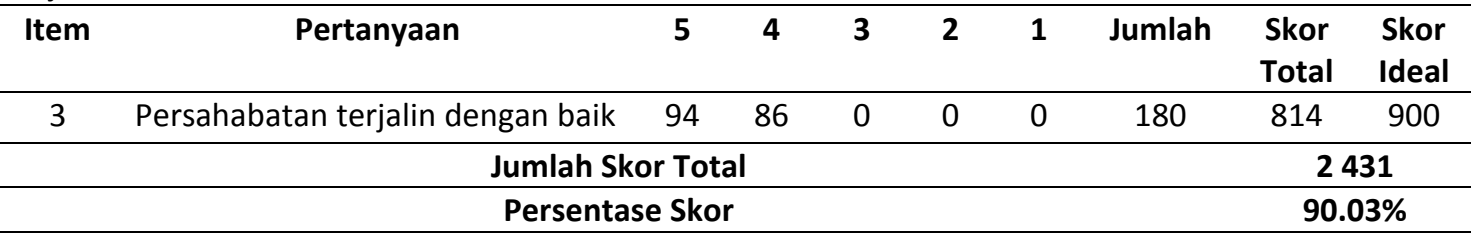

Sumber : Data diolah (2014)

Dari perhitungan dalam tabel menunjukkan nilai yang diperoleh sebesar 2431 atau 90.03\%. Dengan demikian Kebutuhan Afiliasi berada pada kategori sangat tinggi yang menunjukkan bahwa karyawan di Witel Bekasi memiliki motivasi yang tinggi untuk bisa berinteraksi atau memiliki hubungan yang baik dengan orang lain.

3. Analisis Deskriptif Tanggapan Responden Mengenai Kebutuhan Kekuasaan $\left(\mathrm{X}_{3}\right)$

Tabel 6. Tanggapan responden mengenai kebutuhan kekuasaan $\left(\mathrm{X}_{3}\right)$

\begin{tabular}{|c|c|c|c|c|c|c|c|c|c|}
\hline Item & Pertanyaan & 5 & 4 & 3 & 2 & 1 & Jumlah & $\begin{array}{l}\text { Skor } \\
\text { Total }\end{array}$ & $\begin{array}{l}\text { Skor } \\
\text { Ideal }\end{array}$ \\
\hline 1 & Siap menghadapi kompetisi & 76 & 102 & 2 & 0 & 0 & 180 & 795 & 900 \\
\hline 2 & Wewenang sesuai dengan jabatan & 40 & 123 & 17 & 0 & 0 & 180 & 744 & 900 \\
\hline 3 & $\begin{array}{l}\text { Ingin memiliki kedudukan yang } \\
\text { tinggi }\end{array}$ & 50 & 103 & 23 & 4 & 0 & 180 & 740 & 900 \\
\hline \multicolumn{8}{|c|}{ Jumlah Skor Total } & \multicolumn{2}{|c|}{2279} \\
\hline \multicolumn{8}{|c|}{ Persentase Skor } & \multicolumn{2}{|c|}{$84.41 \%$} \\
\hline
\end{tabular}

Sumber : Data diolah (2014)

Dari perhitungan dalam tabel menunjukkan nilai yang diperoleh sebesar 2279 atau $84.41 \%$. Dengan demikian Kebutuhan Kekuasaan berada pada kategori sangat tinggi yang menunjukkan bahwa karyawan di Witel Bekasi memiliki motivasi yang tinggi dalam mencapai suatu kekuasaan atau memiliki pengaruh terhadap orang lain.

\section{III.2. Analisis Deskripsif Tanggapan Responden Mengenai Kinerja Karyawan (Y)}

Kinerja pada dasarnya adalah suatu hasil yang dilakukan oleh karyawan dalam memberikan kontribusi kepada perusahaan. Pada penelitian ini variabel kinerja karyawan digunakan sebagai variabel terikat yang terdiri dari tiga sub variabel dengan dua belas indikator. Sub variabel yang pertama adalah hasil kerja dengan indikator yang digunakan adalah kualitas, kuantitas, ketepatan, dan kecepatan. Sub variabel yang kedua adalah perilaku kerja dengan indikatornya adalah kedisiplinan, kepempinan, ketelitian, dan kerjasama. Sub variabel yang ketiga adalah sifat pribadi yang ada hubungannya dengan pekerjaan dengan indikator yang terdiri dari inisiatif, kejujuran, kemampuan, dan semangat kerja. Berikut ini adalah hasil analisis deskriptif mengenai kinerja karyawan. 


\section{Kinerja Karyawan}

Tabel 7. Tanggapan responden mengenai kinerja karyawan $(\mathrm{Y})$

\begin{tabular}{|c|c|c|c|c|c|c|c|c|c|}
\hline Item & Pertanyaan & 5 & 4 & 3 & 2 & 1 & Jumlah & $\begin{array}{l}\text { Skor } \\
\text { Total }\end{array}$ & $\begin{array}{l}\text { Skor } \\
\text { Ideal }\end{array}$ \\
\hline 1 & $\begin{array}{l}\text { Kualitas pekerjaan sesuai dengan } \\
\text { standar mutu perusahaan }\end{array}$ & 57 & 117 & 6 & 0 & 0 & 180 & 771 & 900 \\
\hline 2 & $\begin{array}{l}\text { Memenuhi target yang telah } \\
\text { ditetapkan }\end{array}$ & 52 & 121 & 5 & 2 & 0 & 180 & 759 & 900 \\
\hline 3 & $\begin{array}{l}\text { Selalu disiplin dalam } \\
\text { meyelesaikan pekerjaan }\end{array}$ & 59 & 116 & 5 & 0 & 0 & 180 & 774 & 900 \\
\hline 4 & $\begin{array}{l}\text { Menyelesaikan pekerjaan dengan } \\
\text { cepat }\end{array}$ & 51 & 119 & 10 & 0 & 0 & 180 & 761 & 900 \\
\hline 5 & Kehadiran wajib tepat waktu & 58 & 110 & 12 & 0 & 0 & 180 & 766 & 900 \\
\hline 6 & $\begin{array}{l}\text { Mampu memimpin rekan-rekan } \\
\text { kerja }\end{array}$ & 43 & 126 & 10 & 1 & 0 & 180 & 749 & 900 \\
\hline 7 & $\begin{array}{l}\text { Tidak melakukan kesalahan dalam } \\
\text { menyelesaikan pekerjaan }\end{array}$ & 77 & 100 & 2 & 1 & 0 & 180 & 791 & 900 \\
\hline 8 & $\begin{array}{l}\text { Lebih menyukai bekerja sama } \\
\text { dengan rekan kerja }\end{array}$ & 85 & 94 & 1 & 0 & 0 & 180 & 804 & 900 \\
\hline 9 & $\begin{array}{l}\text { Memiliki inisiatif dalam } \\
\text { mengusulkan ide cemerlang }\end{array}$ & 55 & 120 & 4 & 1 & 0 & 180 & 767 & 900 \\
\hline 10 & $\begin{array}{l}\text { Jujur dalam melaksanakan setiap } \\
\text { pekerjaan yang diberikan }\end{array}$ & 74 & 104 & 1 & 1 & 0 & 180 & 789 & 900 \\
\hline 11 & $\begin{array}{l}\text { Memiliki kemampuan yang baik } \\
\text { dalam menyelesaikan pekerjaan }\end{array}$ & 63 & 114 & 3 & 0 & 0 & 180 & 780 & 900 \\
\hline 12 & $\begin{array}{l}\text { Memiliki semangat kerja yang } \\
\text { tinggi }\end{array}$ & 78 & 101 & 1 & 0 & 0 & 180 & 797 & 900 \\
\hline \multicolumn{8}{|c|}{ Jumlah Skor Total } & \multicolumn{2}{|c|}{9308} \\
\hline \multicolumn{8}{|c|}{ Persentase Skor } & \multicolumn{2}{|c|}{$86.18 \%$} \\
\hline
\end{tabular}

Sumber : Data diolah (2014)

Dari perhitungan dalam tabel menunjukkan nilai yang diperoleh sebesar 9308 atau $86.18 \%$. Dengan demikian Kinerja Karyawan berada pada kategori sangat tinggi yang menunjukkan bahwa karyawan di Witel Bekasi mampu menghasilkan kinerja yang sangat tinggi.

\section{III.3. Analisis Regresi Berganda}

Analisis regresi linier berganda pada penelitian ini digunakan untuk mengukur besarnya pengaruh variabel bebas yang terdiri dari Kebutuhan Prestasi $\left(X_{1}\right)$, Kebutuhan Afiliasi $\left(X_{2}\right)$ dan Kebutuhan Kekuasaan $\left(X_{3}\right)$ terhadap variabel terikat yaitu Kinerja Karyawan $(\mathrm{Y})$. Model regresi linear berganda dalam penelitian ini adalah:

$$
Y=7.097+0.805 X_{1}+1.439 X_{2}+0.933 X_{3} \ldots \ldots(4)
$$

Keterangan:

1. Nilai konstanta (a) adalah 7.097. Artinya jika Kebutuhan Prestasi, Kebutuhan Afiliasi dan Kebutuhan Kekuasaan nilainya adalah 0 maka Kinerja Karyawan nilainya positif, yaitu 7.097.

2. Nilai koefisien regresi variabel Kebutuhan Prestasi $\left(b_{1}\right)$ bernilai positif, yaitu 0.805 . 
Artinya bahwa setiap pertambahan Kebutuhan Prestasi sebesar satu satuan akan meningkatkan Kinerja Karyawan (Y) sebesar 0.805 dengan asumsi variabel independen lainnya tetap.

3. Nilai koefisien regresi variabel Kebutuhan Afiliasi $\left(b_{2}\right)$ bernilai positif, yaitu 1.439 . Artinya bahwa setiap pertambahan Kebutuhan Afiliasi sebesar satu satuan akan meningkatkan Kinerja Karyawan (Y) sebesar 1.439 dengan asumsi variabel independen lainnya tetap.

4. Nilai koefisien regresi variabel Kebutuhan Kekuasaan $\left(b_{3}\right)$ bernilai positif, yaitu 0.933. Artinya bahwa setiap pertambahan Kebutuhan Kekuasaan sebesar satu satuan akan meningkatkan Kinerja Karyawan (Y) sebesar 0.933 dengan asumsi variabel independen lainnya tetap.

\section{III.4. Pengujian Hipotesis Secara Simultan (Uji F)}

Pengujian hipotesis secara simultan (Uji F) pada penelitian ini digunakan untuk menguji besarnya pengaruh variabel bebbas yang terdiri dari Kebutuhan Prestasi $\left(X_{1}\right)$, Kebutuhan Afiliasi $\left(X_{2}\right)$ dan Kebutuhan Kekuasaan $\left(X_{3}\right)$ secara simultan atau bersamasama berpengaruh terhadapKinerja Karyawan (Y). Berikut ini adalah hasil pengujian hipotesis secara simultan (uji F).

Tabel 8. Hasil Uji F

\begin{tabular}{cc}
\hline F hitung & Sig. $\mathbf{F}$ \\
\hline 71.957 & 0.000 \\
\hline \multicolumn{3}{l}{ Sumber : Data diolah (2014) }
\end{tabular}

Berdasarkan Tabel 8, hasil uji $\mathrm{F}$ diperoleh nilai $\mathrm{F}$ hitung sebesar 71.957 dengan nilai probabilitas (sig) sebesar 0.000 , karena nilai $\mathrm{F}$ hitung lebih besar dari nilai $\mathrm{F}$ tabel (71.957 > 2.655) serta nilai signifikansi kurang dari $0.05(\alpha=5 \%)(0,000<0.05)$ sehingga dapat disimpulkan bahwa variabel bebas yang terdiri dari Kebutuhan Prestasi $\left(X_{1}\right)$, Kebutuhan Afiliasi $\left(X_{2}\right)$ dan Kebutuhan Kekuasaan $\left(X_{3}\right)$ secara bersama-sama (simultan) berpengaruh signifikan terhadap variabel terikat yaitu Kinerja Karyawan di Witel Bekasi.

\section{III.5. Pengujian Hipotesis Secara Parsial (Uji T)}

Pengujian hipotesis secara parsial (uji t) digunakan untuk mengetahui pengaruh variabel bebas yang terdiri dari Kebutuhan Prestasi, Kebutuhan Afiliasi dan Kebutuhan Kekuasaan terhadap Kinerja Karyawan secara parsial. Pada penelitian ini jumlah sampel $(n)$ yang digunakan sebanyak 180 orang dengan taraf signifikansinya sebesar $0.005(5 \%)$, serta drajat kebebasannya (dk) adalah $n-k-1=180-3-1=176$, maka diperoleh nilai $t$ tabel sebesar 1.973. Berikut ini adalah hasil pengujian hipotesis secara parsial (uji t).

Tabel 9. Hasil Uji t

\begin{tabular}{lcc}
\hline \multicolumn{1}{c}{ Variabel Penelitian } & t hitung & Sig. \\
\hline Kebutuhan Prestasi $\left(X_{1}\right)$ & 6.009 & 0.000 \\
Kebutuhan Afiliasi $\left(X_{2}\right)$ & 7.742 & 0.000 \\
Kebutuhan Kekuasaan $\left(X_{3}\right)$ & 4.115 & 0.000 \\
\hline
\end{tabular}

Sumber : Data diolah (2014) 
Berdasarkan Tabel 9, hasil uji $t$ pada variabel Kebutuhan Prestasi $\left(X_{1}\right)$ menunjukkan bahwa nilai $t$ hitung yang diperoleh adalah 6.009 dengan nilai probabilitas (sig) sebesar 0.000 , hal ini berarti nilai t hitung lebih besar dari pada nilai $t$ tabel $(6.009>1.973)$ dan nilai probabilitas (sig) yang dihasilkan lebih kecil dari $0.05(\alpha)$ $(0.000<0.05)$. Hasil nilai t hitung pada variabel Kebutuhan Afiliasi $\left(\mathrm{X}_{2}\right)$ adalah 7.742 dengan nilai probabilitas (sig) sebesar 0.000 , artinya nilai t hitung lebih besar dari pada nilai t tabel $(7.742>1.973)$ dan nilai probabilitas $(\mathrm{sig})$ yang dihasilkan lebih kecil dari $0.05(\alpha)(0.000<0.05)$. Variabel Kebutuhan Kekuasaan $\left(X_{3}\right)$ memiliki nilai t hitung sebesar 4.115 yang berarti nilai t hitung yang dihasilkan lebih besar dari nilai t tabel $(4.115>1.973)$, selain itu nilai probabilitas (sig) yang dihasilkan memiliki nilai yang lebih kecil dari $0.05(\alpha)(0.000<0.05)$. Berdasarkan hasil tersebut dapat disimpulkan bahwa Kebutuhan Prestasi $\left(X_{1}\right)$, Kebutuhan Afiliasi $\left(X_{2}\right)$ dan Kebutuhan Kekuasaan $\left(X_{3}\right)$ secara parsial berpengaruh signifikan terhadap Kinerja Karyawan Witel Bekasi.

\section{III.6. Analisis Pengaruh Parsial}

Analisis pengaruh parsial digunakan untuk mengetahui seberapa erat pengaruh dari masing-masing variabel bebas terhadap variabel terikat. Pada penelitian ini analisis pengaruh parsial di gunakan untuk mengetahui bagaimana besarnya pengaruh dari variabel Kebutuhan Prestasi $\left(X_{1}\right)$, variabel Kebutuhan Afiliasi $\left(X_{2}\right)$ dan Kebutuhan Kekuasaan $\left(\mathrm{X}_{3}\right)$ secara parsial terhadap variabel kinerja karyawan $(\mathrm{Y})$. Berikut ini adalah hasil analisis pengaruh parsial.

Tabel 10. Hasil analisis pengaruh parsial

\begin{tabular}{ccccc}
\hline Variabel & $\begin{array}{c}\text { Standardized } \\
\text { Coefficients Beta }\end{array}$ & $\begin{array}{c}\text { Correlation } \\
\text { Zero-Order }\end{array}$ & $\begin{array}{c}\text { Besarnya Pengaruh } \\
\text { Secara Parsial }\end{array}$ & $\begin{array}{c}\text { Besarnya Pengaruh } \\
\text { Secara Parsial (\%) }\end{array}$ \\
\hline X1 & 0.351 & 0.575 & 0.201 & 20.1 \\
X2 & 0.410 & 0.561 & 0.230 & 23 \\
X3 & 0.238 & 0.501 & 0.120 & 12 \\
\hline \multicolumn{7}{r}{} & & $\mathbf{0 . 5 5 1}$ & $\mathbf{5 5 . 1}$ \\
\hline
\end{tabular}

Sumber : Data diolah (2014)

Pengaruh parsial diperoleh dengan mengalikan nilai standardized coefficients beta dengan nilai correlation zero-order. Berdasarkan Tabel 10, hasil analisis pengaruh parsial menunjukkan bahwa besarnya pengaruh Kebutuhan Prestasi $\left(\mathrm{X}_{1}\right)$ terhadap Kinerja Karyawan (Y) secara parsial adalah sebesar 20.1\%, besarnya pengaruh Kebutuhan Afiliasi $\left(\mathrm{X}_{2}\right)$ terhadap Kinerja Karyawan $(\mathrm{Y})$ secara parsial adalah sebesar $23 \%$, dan besarnya pengaruh Kebutuhan Kekuasaan $\left(X_{3}\right)$ terhadap Kinerja Karyawan $(Y)$ adalah sebesar $12 \%$. Jadi total keseluruhan pengaruh Kebutuhan Prestasi $\left(\mathrm{X}_{1}\right)$, Kebutuhan Afiliasi $\left(X_{2}\right)$ dan Kebutuhan Kekuasaan $\left(X_{3}\right)$ terhadap Kinerja Karyawan $(Y)$ secara bersama-sama adalah sebesar $55.1 \%$. Hasil total keseluruhan pengaruh dari semua variabel bebas $\left(X_{1}, X_{2}\right.$, dan $\left.X_{3}\right)$ akan terlihat sama dengan nilai koefisien determinasinya.

\section{III.7. Koefisien Determinasi}

Koefisien determinasi digunakan untuk melihat seberapa besar kontribusi variabel bebas yang terdiri dari Kebutuhan Prestasi $\left(X_{1}\right)$, Kebutuhan Afiliasi $\left(X_{2}\right)$ dan 
Kebutuhan Kekuasaan $\left(\mathrm{X}_{3}\right)$ terhadap Kinerja Karyawan $(\mathrm{Y})$ secara keseluruhan. Berikut ini adalah hasil koefisien determinasi.

Tabel 11. Koefisien determinasi

\begin{tabular}{ccccc}
\hline Model & $\mathbf{R}$ & R Square & $\begin{array}{c}\text { Adjusted } \mathbf{R} \\
\text { Square }\end{array}$ & $\begin{array}{c}\text { Std. Error of the } \\
\text { Estimate }\end{array}$ \\
\hline 1 & $0.742^{\text {a }}$ & 0.551 & 0.543 & 4.7044407 \\
\hline
\end{tabular}

Sumber: Data diolah (2014)

Berdasarkan Tabel 11 dapat dilihat bahwa nilai R (nilai korelasi berganda) yang dihasilkan adalah sebesar 0.742 dan nilai $R$ square $\left(R^{2}\right)$ atau koefisien determinasi adalah sebesar 0.551. Angka tersebut digunakan untuk melihat besarnya kontribusi Kebutuhan Prestasi, Kebutuhan Afiliasi dan Kebutuhan Kekuasaan terhadap Kinerja Karyawan. Adapun cara untuk menghitung R square atau koefisien determinasi adalah sebagai berikut:

$$
\begin{aligned}
\mathrm{KD} & =r^{2} \times 100 \% \\
& =(0.742)^{2} \times 100 \% \\
& =0.551 \times 100 \% \\
& =55.1 \%
\end{aligned}
$$

Hasil perhitungan di atas menunjukkan bahwa koefisien determinasi adalah sebesar 55.1\%. Hal ini menunjukkan bahwa besarnya pengaruh variabel Kebutuhan Prestasi, Kebutuhan Afiliasi dan Kebutuhan Kekuasaan terhadap variabel Kinerja Karyawan adalah sebesar $55.1 \%$, sedangkan sisanya $44.9 \%$ dipengaruhi oleh variabel lain yang tidak diteliti dalam penelitian ini.

\section{Kesimpulan}

Variabel motivasi kerja pada penelitian ini terdiri dari tiga variabel, yaitu Kebutuhan Prestasi $\left(X_{1}\right)$, Kebutuhan Afiliasi $\left(X_{2}\right)$ dan Kebutuhan Kekuasaan $\left(X_{3}\right)$. Berdasarkan hasil penelitian, variabel motivasi kerja secara simultan dan parsial memiliki pengaruh positif dan signifikan terhadap kinerja karyawan Witel Bekasi. Variabel kebutuhan afiliasi memiliki pengaruh yang paling besar terhadap kinerja yang dihasilkan oleh karyawan. Hal ini berarti bahwa semakin besar motivasi akan kebutuhan afiliasi yang terpenuhi maka akan semakin besar pula kualitas kinerja yag dihasilkan oleh karyawan Witel Bekasi. Variabel kebutuhan prestasi memiliki pengaruh terbesar kedua terhadap kinerja karyawan, hal ini berarti bahwa semakin tinggi motivasi karyawan akan kebutuhan berprestasi maka semakin tinggi pula kinerja yang akan dihasilkan oleh karyawan Witel Bekasi. Variabel kebutuhan kekuasaan memiliki pengaruh yang paling kecil terhadap kinerja karyawan, artinya karyawan Witel Bekasi tidak terlalu memerlukan motivasi kebutuhan kekuasaan untuk menghasilkan kinerja yang baik. 


\section{Daftar Pustaka}

Abdurrahman M, Muhidin SA, Somantri A. 2011. Dasar-Dasar Metode Statistika Untuk Penelitian. Bandung (ID): Pustaka Setia.

Hamid N. 2012. Pengaruh Kepemimpinan, Motivasi dan Stres Kerja terhadap Kinerja Karyawan pada Bank Syariah Mandiri Kantor Cabang Makassar. Jurnal Analisis, 1 (1): 87-93.

Mangkunegara AAAP. 2007. Manajemen Sumber Daya Manusia Perusahaan (Cetakan Ketujuh). Bandung (ID): Rosda.

Murti H, Veronika AS. 2013. Pengaruh Motivasi terhadap Kinerja Pegawai dengan Variabel Pemediasi Kepuasan Kerja pada PDAM Kota Madiun. Jurnal Riset Manajemen dan Akuntansi, 1(1): 10-17.

Permansari R. 2013. Pengaruh Motivasi dan Lingkunagan Kerja terhadap Kinerja Karyawan PT Anugrah Raharjo Semarang. Management Analysis Journal, 2(2): 19.

Riduwan. 2009. Pengantar Statistika Sosial (Cetakan Kedua). Bandung (ID): Alfabeta.

Salleh F, Dzulkifli Z, Wan Abdullah WA, Yakoob NHM. 2011. The Effect of Motivation on Job Performance of Stage Government Employees in Malaysia. International Journal of Humanities and Social Science, 1(4): 147-154.

Sanusi A. 2011. Metode Penelitian Bisinis. Jakarta (ID): Salemba Empat.

Sedarmayanti, Hidayat S. 2011. Metodologi Penelitian (Cetakan Kedua). Bandung (ID): Mandar Maju.

Sugiyono. 2011. Metode Penelitian Kuantitatif, Kualitatif, dan R\&D. Bandung (ID): Alfabeta.

Susan WM, RW Gakure, EK Kiraithe, AG Waititu. 2012. Influence of Motivation on Performance in the Public Security Sector with a Focus to the Police Force iin Nairobi, Kenya. International Journal of Business and Social Science, 3(23): 195204.

Suwardi, Joko U. 2011. Pengaruh Motivasi Kerja, Kepuasan Kerja dan Komitmen Organisasional terhadap Kinerja Pegawai (Studi pada Pegawai Setda Kabupaten Pati). Analisis Manajemen, 5(1): 75-86.

Telkom Indonesia. 2013. Tentang Perusahaan. [internet]. [diundauh pada 2014 April 22]. Tersedia pada: http://www.bumn.go.id/telkom/tentang-kami/tentangperusahaan.

Umar H. 2008. Metode Penelitian untuk Skripsi dan Tesis Bisnis (Edisi Kedua). Jakarta (ID): Rajawali Pers.

Wirawan. 2009. Evaluasi Kinerja Sumber Daya Manusia. Jakarta (ID): Salemba Empat. 